\title{
Stewardship and the insolvency practitioner: a review of the current position
}

\author{
by David Milman
}

\section{INTRODUCTION}

When analysing the many complex issues thrown up by the ongoing corporate governance debate our focus tends to settle on well-intentioned prescriptions for the orderly running of a solvent concern, particularly a listed company. But when reviewing the extant body of scholarship on corporate governance we should recognise the fact the overwhelming majority of companies are not listed, so they fall outside the scope of many "soft law" codes. We also note that many companies fail to live up to these expectations and ultimately fail, though not necessarily because of any such corporate governance lapses themselves but rather because of the fundamental economics underpinning the business model.

Where business failure occurs, it is important that the incumbent directors do not try to informally wind down the business; that falls outside their remit - see Re Ipcon Fashions Ltd (1989) 5 BCC 733. Rather, a new management regime should then be installed in the form of an independent and professionally qualified insolvency practitioner, whose function as office holder will be either to achieve rehabilitation or (more usually) to perform an efficient burial in accordance with the norms of distributional justice. This office holder in that capacity as successor-manager will also have a responsibility to ensure that the previous management has lived up to required standards established for company directors. Scrutiny of managerial conduct in the twilight zone is essential and powers of investigation may have to be deployed, followed up by litigation if required. But it must never be forgotten that many comparable governance standards now also apply to the actions of insolvency office holders themselves and therefore it is universally accepted that effective mechanisms should exist to promote adherence to these standards. The purpose of this short article is to highlight in this context of the discharge of stewardship responsibilities by insolvency office holders a number of governance-related issues worthy of further exploration.

\section{DEFINITIONAL AND STATUS ISSUES}

One initial problem confronting any researcher into the regulation of insolvency practitioners is that they operate under various legal guises and this has the potential to sow the seeds of confusion. Although the basic term "insolvency practitioner" is well established in the legislative matrix (see Insolvency Act 1986 s 388) we also have to grapple with the variable category of "office holders" (Insolvency Act 1986 ss 230 et seq), "officers of the court" (a common law idea the scope of which is not entirely clear) and now "appointees" (Practice Direction: Insolvency Proceedings [2012] BCC 265). Surely, there must be scope for some rationalisation of legal designation here.

There are other status issues to get to grips with. Insolvency practitioners are invariably installed as agents of the company (for confirmation of this with regard to administrative receivers and administrators see for example Insolvency Act 1986 s 44(1)(a) and Sched B1 para 69 respectively). Significant modern authorities confirming this position in the case of receivers include Mills $v$ Birchall [2008] EWCA Civ 385, [2008] BCC 471 and Edenwest Ltd v CMS Cameron McKenna [2012] EWHC 1258 (Ch), where Hildyard J undertook (at paras [60] to [72]) a valuable analysis of the implications of this agency. This agency nexus results in office holders assuming a status as fiduciaries. A number of consequences and duties naturally flow from this position of peculiar responsibility. For instance, there is an obligation not to permit a conflict of interest, or to acquire an inappropriate profit from one's position as a steward. These particular obligations are reflected both by the Insolvency Act 1986 and by the Insolvency Rules 1986 (SI 1986/1925) - for liquidators see in this context Insolvency Rule 4.149. There is also a duty imposed on insolvency practitioners not to compromise their professional independence by becoming too close to any particular stakeholder. Compliance with this latter requirement can be challenging as the realities are that certain insolvency practitioners will often have a close and repeat relationship with a particular stakeholder, such as a secured creditor. 
By way of clarification we observe that insolvency office holders, rather like directors, do not generally occupy a position as a trustee, though their obligations may often be comparable. Occasionally, a trustee status arises in respect of an insolvency practitioner; for example, the supervisor of a company voluntary arrangement will hold funds collected during the CVA as trustee for participating creditors.

\section{APPOINTMENT TO OFFICE}

Access to the stewardship of a company via taking up office as an insolvency practitioner is tightly controlled in the UK. It is only available to individuals (as opposed to corporate bodies) and since 1985 such individuals must be professionally qualified/ regulated. A bond must also be lodged as a form of financial security. These are important foundations recommended by the Cork Committee on Insolvency Law and Practice (Cmnd 8558, 1982) and are designed to promote good stewardship. They compare favourably with the relatively lax rules operating on the qualification to be a company director and on the ability to access limited liability at minimal financial cost.

There have been a number of recent authorities that throw light on the regulatory environment related to appointment of insolvency office holder. Sometimes two equally worthy insolvency practitioners are nominated as office holders by different stakeholders. How to choose between them? This was the predicament faced by Morgan J in Healthcare Management Services Ltd v Caremark Properties [2012] EWHC 1693 (Ch) where an application had been made to the court by an unsecured creditor for the appointment of an administrator. The applicant had a nominee in mind for the post of administrator as did another unsecured creditor. The pragmatic solution adopted by Morgan J was to appoint the nominee of the creditor who was owed the larger debt. This tiebreaker methodology was possible as both nominees were equally acceptable.

The issue of directors appointing administrators out of court pursuant to paragraph 22 of Schedule B1 of the Insolvency Act 1986, a scenario that was intended to reduce the role of the court, has ironically generated much litigation in the wake of the ruling of Chancellor Sir Andrew Morritt in Minmar [2011] EWHC 1159 (Ch), [2011] BCC 485. Although the decision in that case was clearly merited on the facts, for many judges the suggestion that the appointment of the administrator would be deemed invalid because the directors had failed to notify the company itself seemed too pernickety, and in a number of first instance authorities they lined up to voice their opposition. Other judges supported strict adherence to the formal requirements. Constructive solutions to this procedural irregularity that avoided the need to invalidate the administration were also put forward with the focus of attention being upon retrospective judicial validation relying on the precedent of Re G-Tech Construction Ltd [2007] BPIR 1275, or exploitation of the untapped potential of para 104 of Sched B1.
In Re BXL Services [2012] EWHC 197 (Ch), [2012] BCC 657 HHJ Purle QC, when reviewing the extant jurisprudence, opined that in the wake of the large number of first instance authorities on the subject the law was now settled in favour of a more flexible approach. One can only hope that this prediction remains the case, and certainly there has been a marked decrease in reported litigation on this point in the past six months. Moving away from the narrow "paragraph 22" issue there is the wider question of the extent to which procedural irregularities in the appointment of an office holder can be whitewashed. We note here the provision found in Insolvency Rule 7.55 which enables the court to forgive procedural irregularity in the context of insolvency proceedings and the differing outcomes in the courts as reflected in administration cases such Re Euromaster Ltd [2012] EWHC 2356 (Ch), [2012] BCC 754 (a decision of Norris J) and Re Eco Link Resources [2012] BCC 751 (per HHJ David Cooke). The former involved a minor lapse in the appointment of an administrator one day after the notice of intention to appoint had expired, whereas the latter case was concerned with failure to give notice to a prior chargeholder. It is therefore a matter of degree as to whether Insolvency Rule 7.55 will come into play. As always, practitioners should not place their reliance upon a benign judicial view of any procedural shortcoming.

\section{THE BASIC ROLE OF THE INSOLVENCY OFFICE HOLDER}

This will, of course, vary depending upon the precise insolvency regime involved. If we take the paradigm case of liquidation, clearly the central function is to collect, realise and distribute the assets (Insolvency Act 1986 s 143(1)). There is an obligation under section 144 to take custody of the company's assets. But it is often overlooked that insolvency practitioners are there to protect the public interest in terms of the way in which limited liability operates - for example by reporting the names of directors who appear to be unfit to the authorities as they are obliged to do by section 7(3) of the Company Directors Disqualification Act 1986. Powers of investigation conferred on office holders can quite properly be utilised with that purpose in mind. A perusal of the judgment of Lord Millett in Official Receiver $v$ Wadge, Rapps and Hunt [2003] UKHL 49, [2004] 1 AC 158 will serve to confirm that wider perspective.

In other cases, the role of the insolvency office holder may focus upon rescue and actions taken should reflect that goal. For the most parts the courts have been supportive of the pro-rescue philosophy embraced by successive governments and it is therefore easy to understand why the odd ruling that goes against the flow may generate a disproportionate outcry.

The basic task of insolvency office holders these days often involves confronting cross border insolvency complications as assets and debts may be located in several 
jurisdictions. Fortunately, there have been positive reforms made in the law via the EC Regulation on Insolvency Proceedings (1346/2000) and the Cross Border Insolvency Regulations 2006 (SI 2006/1030) (which seek to implement the UNCITRAL Cross Border Model Insolvency Law). These developments in cross border cooperation undoubtedly have made life easier for UK insolvency practitioners (and, incidentally, have generated more work via "imported" insolvency cases). But they have not been the only beneficiaries of this outbreak of comity. In Re Chesterfield United Inc [2012] EWHC 244 (Ch), [2012] BCC 786 Newey J has confirmed that on an application under Art 21 of Cross-Border Insolvency Regulations 2006 the use of section 236 investigation powers under the Insolvency Act 1986 can be offered to foreign insolvency office holders. This ruling is consistent with the pro comity attitudes applied by the English courts when dealing with requests under section 426 of the Insolvency Act 1986 for insolvency assistance from foreign courts based in designated jurisdictions.

Generally speaking, the common law has over the past decade also moved in a favourable direction in terms of facilitating insolvency practice in cross border cases, though that development has been thrown into question in view of the ruling of the Supreme Court in Rubin $V$ Eurofinance SA [2012] UKSC 46, [2012] 3 WLR 1019. It remains to be seen whether this particular precedent is but a temporary setback, or an indicator of future judicial attitudes. Whatever, the relative importance of the legislative pro comity mechanisms has been reinforced by this judgment.

\section{THE POWERS AND RIGHTS OF INSOLVENCY PRACTITIONERS}

The reforms enacted in the Insolvency Act 1986 have certainly improved the armoury of the insolvency practitioner, both with regard to powers of investigation and follow up action (whether it take the form of a recovery claim against a company officer or an application to set aside an improper transaction). But there is scope for improvement, particularly with regard to administrators whose role has expanded considerably since the Enterprise Act 2002 took effect in September 2003. The gap between administrators and liquidators has narrowed in terms of the role they play. Many administrations are in effect disguised liquidations and administrators enjoy statutory powers of distribution. So, why should administrators not be given the power to bring wrongful trading claims pursuant to section 214 of the Insolvency Act 1986? What now is the logic in denying administrators an explicit power to disclaim onerous assets (see Insolvency Act 1986 s 178)? These inconsistencies are not isolated - witness the curious differential in the relative powers of distribution of liquidators and administrators (and CVA supervisors), as commented upon by Newey J in Re TXU Europe Group pc [2011] EWHC 2072 (Ch), [2012]
BCC 363 at para [20]. There is a need for more joined up thinking in the future when the law is reviewed.

One provision which is expressly applicable to administrations is section 234 of the Act, which enables office holders to apply to the court to recover company property and books held by third parties. This facility was considered by Sir Andrew Morritt in Re La Senza SA (Uniserve v Croxen) [2012] EWHC 1190 (Ch). As it transpired, the court refused to allow administrators to recover company property in the hands of hauliers until a lien in favour of those same hauliers for unpaid carriage costs had been discharged.

We could also note section 233 of the Act, which prevents monopoly utility suppliers from withholding essential supplies to office holders unless they settle pre appointment arrears.

The pursuit of recovery claims (wrongful trading, misfeasance or avoidance claims) is dependent upon available litigation finance. The threat posed by the Legal Aid, Sentencing and Punishment of Offenders Act 2012 to the use of conditional fee agreements and after the event insurance in this context has been successfully resisted by the insolvency profession via concessions granted in respect of the application of the provisions in sections 44 and 46 of the 2012 Act, But these concessions are only temporary and are due to expire in April 2015. For further information see Ministerial Statement of Jonathan Djanogly on behalf of the Ministry of Justice dated May 24, 2012.

\section{DUTIES OF INSOLVENCY PRACTITIONERS}

These are mainly contained in the common law or through the provisions of the Insolvency Act 1986, though general legislation can impose particular responsibilities (for example, with regard to the safeguarding of employee rights, promoting environmental protection and the prevention of money laundering). Insolvency practitioners are not subject to the duty to have regard to stakeholders created by section 172 of the Companies Act 2006, but in reality that matters little in the light of these discrete and significant legal responsibilities. Taking an overview of the responsibilities of insolvency office holders one is tempted to observe there is a need to develop a core statutory code along the lines of that applied to company directors by sections 170-177 of the Companies Act 2006.

A fundamental obligation of stewardship is that of competence. For some insolvency practitioners this obligation has been developed through court decision. We can now assume, in spite of Downsview Nominees v First City Corporation [1993] AC 295, that receivers owe a duty not merely to act in good faith but also to take reasonable care. This more onerous standard was confirmed by the Court of Appeal in Medforth ${ }_{v}$ Blake [2000] Ch 86. The precise relationship between these two authorities and the scope of this duty may not always be entirely clear cut, but there is 
an illuminating discussion in the judgment of Edward Bartley Jones QC (sitting as a Deputy Judge of the High Court) in International Leisure Ltd v First National Trustee Co Ltd [2012] EWHC 1971 (Ch), [2012] BCC 738. For other insolvency practitioners, such as administrators, standards of competence/efficiency are written into the statutory matrix under which they operate - so for administrators we note the terms of Insolvency Act 1986, Schedule B1, paragraph 4. More recently, in McAteer v Lismore [2012] NICh 7, [2012] BPIR 812 it was held by Deeny J that trustees in bankruptcy owe a duty to take reasonable care to obtain the best possible price in realising assets included in the estate. The overall trend here is clear, and, it is submitted, entirely consistent with the expectations of professionalism. Any attempt to undermine this development or to curb duties of competence would not be in the long term interests of the insolvency profession.

Insolvency practitioners are under a range of positive obligations. So they are obliged to take control of the company's assets - Insolvency Act 1986 section 144. There is according to Pulsford v Devenish [1903] 2 Ch 625 a proactive duty to contact known creditors, and they must ensure that preferential claims are met out of floating charge realisations. A similar distributional obligation now operates in respect of the claims of unsecured creditors to be paid from the reserved fund (or prescribed part) established by section 176A of the Insolvency Act 1986. An office holder wishing to disapply this obligation (where, for example, it might be uneconomical to operate it) should seek the permission of the court (see s 176A(5)).

We have noted above that many insolvency office holders are treated in law as officers of the court; this confers protection upon them, but also results in the imposition of peculiar responsibilities. For example, the duty to act honourably, as prescribed by the 19th century ruling in $E x$ parte James (1874) LR 9 Ch App 609. In modern times this duty has lost much of its value and is increasingly subordinated to the obligation to realise assets in the interest of the legitimate stakeholders. The Wedgwood Museum Trust case [2011] EWHC 3782 (Ch), where the pressing need to meet legitimate creditor claims out of what were found to be the company's assets trumped the desirability of protecting the national heritage in ceramics, attested to this reality without the court having specifically to address the ex parte James (supra) point. In later proceedings in this case reported in [2012] EWHC 1974 (Ch) HHJ Purle QC stressed the need for the exercise of economy on the part of an insolvency office holder in engaging legal representation. The duty to act honourably is but part of the package of responsibilities that flows from being an officer of the court. Witness here the cautionary observations of Lord Hodge made in the Court of Session (Outer House) in Re Quantum Distribution (UK) Ltd [2012] CSOH 191 on 18 December 2012.

The seven recognised professional bodies, in association with the competent authorities, have for the past two decades formulated Statements of Insolvency Practice ("SIPs"). These seek both to inform insolvency practitioners and to highlight good practice. In some aspects of insolvency practitioner work their observance is particularly important. Witness SIP 16 (first issued in 2009) and the use by administrators of the "prepack" procedure where, increasingly, judicial approval is contingent upon compliance with SIP 16 - see for example Re Kayley Vending Ltd [2009] EWHC 904 (Ch), [2009] BCC 578, Re Halliwells LLP [2010] EWHC 2036 (Ch), [2011] BCC 57 and Re European Directories (DH6) BV [2010] EWHC 3472 (Ch), [2012] BCC 46. The Insolvency Service has invested considerable time in monitoring on a six monthly basis compliance with this standard. Improved compliance rates have both forestalled threatened legislation and, to some extent, allayed public concern. But compliance with SIP 16 is no guarantee of judicial backing for a proposed prepack, as HHJ Purle QC observed in Re UK Steelfixers Ltd [2012] EWHC 2432 (Ch), [2012] BCC 751.

Insolvency practitioners, by virtue of their membership of professional associations, are committed to observe professional codes of ethics. It is often assumed that these lack teeth - but this is a misconception, partly fuelled by a lack of public awareness as to how the system works. The Insolvency Service publishes an Annual Review of Insolvency Practitioner Regulation detailing the sanctions visited against errant office holders. These range from cautions to the imposition of financial penalties. Ultimately, the Insolvency Service can disqualify an insolvency practitioner from holding office by withdrawing a licence. The Insolvency Practitioners Tribunal can deal with disputes over licensing, but apparently cases coming before it are very rare occurrences.

The director disqualification regime ironically may also be deployed against an errant insolvency practitioner - for discussion of the possibilities here in relation to s. 4 of the Company Directors Disqualification Act 1986 see the judgment of Newey J in Wood v Mistry [2012] EWHC 1899 (Ch).

\section{REVIEWING THE EXERCISE OF POWERS}

Once a company has become insolvent and has been handed over to an office holder, the ability of shareholders to restrain management is eclipsed. As their tangible interest in the company has gone, so their corresponding rights are largely diluted. But insolvency office holders (particularly those classed as officers of the court) do not operate in English without any form of supervision. They can be called to account via a variety of mechanisms. So, for example, there are procedures under which dissatisfied interest parties can complain to the court - Insolvency Act 1986 sections 7(3), 167(3) and 168(5) and Sched B1 para 74. A liquidator may be subject to a misfeasance claim under section 212 of the Insolvency Act 1986 - Re Centralcrest Ltd [2000] BCC 727. A comparable example of this form of accountability in the case of administrators is 
provided by paragraph 75 of Schedule B1 of the Insolvency Act 1986.

Very often when the exercise of powers is challenged in court the office holder can seek solace in the Wednesbury test (Associated Provincial Picture Houses $v$ Wednesbury Corporation [1948] 1 KB 223). The courts traditionally have been disinclined to intervene with a matter of professional judgement unless Wednesbury unreasonableness is established. But in Bramston v Haut [2012] EWHC 1279 (Ch) (a case on personal insolvency) Arnold J at first instance argued that the Wednesbury test is now viewed as a flexible standard and that each case does turn on its own individual facts - see paragraph [42]. This might have suggested that a more interventionist style could be adopted for the future when reviewing the conduct of insolvency practitioners. However, on appeal, the Court of Appeal ([2012] EWCA Civ 1637) reverted to the more orthodox analysis and concluded in its judgment of December 14, 2012 that the court should only interfere with decisions of insolvency practitioners if they can truly be seen as perverse - see Kitchin LJ at paras [69]-[72].

\section{REWARDING STEWARDSHIP AND REIMBURSING PROPERLY INCURRED EXPENSES}

Insolvency practitioners have a legitimate expectation that they will be paid for their work and that their out of pocket expenses will be met. As ever, this is a contentious issue because this prioritised claim may have the effect of further marginalising unsecured creditors. In the aftermath of the Maxwell affair (where, incidentally, the costs of the insolvency process were largely upheld on review - see [1999] BCC 684) we saw in December 2002 the revision of Statement of Insolvency Practice 9 This was then followed by the 2004 Practice Direction of Chief Registrar Baister on the Remuneration of Court Appointees [2004] BCC 912, the provisions of which were then reproduced in 2012 as Part Five of the Practice Direction: Insolvency Proceedings (reported in [2012] BCC 409). Transparency and value for money became the critical factors. The importance of adherence to this standard was confirmed by the Court of Appeal in Brook $v$ Reed [2011] EWCA Civ 331, [2012] 1 WLR 419. Further pro transparency measures were enacted through the Insolvency (Amendment) Rules 2005 (SI 2005/512) with the introduction of Regulation 36A into the Insolvency Regulations 1994 (SI 1994/2507). When applying these rules the courts do recognise that particularly difficult cases may be more expensive to resolve - Re Super Aguri Ltd [2011] BCC 452. In spite of these positive moves, there is still public concern expressed about the cost of the insolvency process, though, as we note below, this concern often misses the point.

As far as administrators are concerned, we note the Schedule B1 paragraph 99 charge which is designed to protect their claim for fees earned and expenses incurred.
In Re MK Airlines Ltd [2012] EWHC 1018 (Ch) Morritt C observed (at para [26]) that the para 99 charge can be enforced by appointment of a receiver. The Chancellor also offered important guidance on the pool of assets covered by the paragraph 99 charge. It remains to be seen if administrators will use this strategy when claiming their due from successor office holders.

The question of insolvency expenses is addressed by legislation in some detail and it is clear from Re Toshoku Finance UK plc [2002] UKHL 6, [2002] 1 WLR 671 that the courts are under an injunction to maintain the stated legislative priorities. That might suggest a degree of certainty, however, the treatment of administration expenses is the subject of much discussion at present as we await the Supreme Court's pronouncement on the appeal in Bloom $v$ Pensions Regulator [2011] EWCA Civ 1124, [2012] BCC 83. A useful indicator of the complexity of the law on insolvency expenses can be gleaned from a perusal of the impressive judgment of Morgan $\mathrm{J}$ in Neumans LLP Andronikou [2012] EWHC 3088 (Ch), where the balkanised nature of the insolvency expenses regime(s) is clearly apparent.

\section{REMOVING INSOLVENCY PRACTITIONERS FROM OFFICE}

Any properly instituted stewardship regime must admit the possibility of misbehaviour/ disputation between the office holder and stakeholders and must therefore make available effective removal procedures. Insolvency office holders cannot be removed at the whim of their appointors. This security of tenure applies even to administrative receivers, as is confirmed by section 45(1) of the Insolvency Act 1986 and considered in Re A \& C Supplies Ltd [1998] BPIR 303. This reflects the importance of the office held.

In the case of insolvency office holders, we should note that proof of misbehaviour is not seen as a prerequisite for removal. The critical issue is one of confidence, or the loss of it. That said, the courts are reluctant to order removal. There are two primary reasons for this. First of all, as intimated above, the courts respect the professional judgment of insolvency practitioners and are aware that their (proper) actions may arouse hostility. There is also the disruption cost associated with any change of office holder. So in Finnerty v Clark [2011] EWCA Civ 858, [2011] BCC 702 the Court of Appeal (upholding a judgment of Morritt C) refused to remove administrators who had declined to undertake a speculative claim based on section 244 of the Insolvency Act 1986, even though they were being offered a protective indemnity against costs. The professional judgement of the administrators deserved respect. Again, in Re Kimberley Scott Services Ltd [2011] EWHC 1563 (Ch), [2012] BPIR 135 Norris J rejected an application to remove liquidators and placed great emphasis upon the potential disruption that would be generated by a change of stewardship. For later 
proceedings before Norris $\mathrm{J}$ on the issue of the costs of this removal application see [2011] EWHC 3865 (Ch), [2012] BPIR 341. A similar supportive attitude manifested itself in the judgment of Mrs Justice Proudman in Doffman and Isaacs $v$ Wood and Hellard [2011] EWHC 4008 (Ch), [2012] BPIR 972 where an application to remove trustees in bankruptcy was dismissed, but on specified terms.

\section{REFORM AND POLICY ISSUES: FUTURE DEVELOPMENTS?}

Those responsible for the development of English law (and the insolvency profession itself) can congratulate themselves on the steps they have taken to improve standards of stewardship in terms of the role played by insolvency office holders. The World Bank Doing Business survey in 2012 also gives the UK a high rating for the effectiveness its insolvency regime in resolving cases efficiently. Apparently, the UK is the sixth most highly rated jurisdiction for the efficiency of its insolvency regime; the only other aspect of UK business regulation that receives a better rating is its system of offering credit. But in an increasingly competitive world, it is never a good idea to rest on one's laurels.

There are a number of issues that could be the subject of constructive reflection.

Firstly, what relevance does the gender debate, that is currently the subject of media and policymaker attention with regard to the composition of boards of company directors, have in the context of the current profile of insolvency office holders? The key stakeholders in the profession should certainly have this question under review.

Should there be further steps taken to coordinate the handling of complaints against office holders? Is it time to revisit the Cork Committee's idea of establishing an Insolvency Ombudsman (1982, Cmnd 8558 para 1772)? The profession has in the past appeared to be in two minds on the merits of such a move and, in fairness, there is little to suggest that the current system is failing, but public perceptions do matter and other professions have moved in this direction. The Office of Fair Trading report in June 2010 (The Market for Corporate Insolvency Practitioners, OFT1245) favoured moves in this direction with the setting up of an independent complaints body (see paras 1.26-1.29), but it appeared as a result of the Insolvency Service Consultation on Reforms to the Regulation of Insolvency Practitioners, which was published on December 20, 2011 (at pp 7-9), that there was a lack of consensus on the form and financing of any independent complaints mechanism. The latest developments here are more encouraging with the announcement by Business Minister Jo Swinson of the DBIS on December 20, 2012 that Professor Elaine Kempson will conduct a review of returns to unsecured creditors and insolvency practitioner remuneration, with the results of this review expected to be available in summer 2013. In the meantime a package of reforms will be put in place by the regulators and the Insolvency Service in March which will seek to provide a single gateway for complaints and greater coordination on the application of sanctions against those insolvency practitioners who are found to fall short of required standards. Improved transparency will also be introduced to reassure the public of the seriousness with which complaints are viewed by the regulatory authorities.

Should we move away from the idea of appointment of insolvency office holders in personam to a recognition of corporate office holders? This would avoid many of the problems that can arise with regard to block transfers of office, but would this undermine standards of professionalism? The debate is finely balanced here.

Can we develop more efficient procedures to clarify the law as practised by insolvency office holders? Admittedly, all office holders have access to a directions facility, but this is subject to the vagaries of our judicial system. Directions given by first instance judges can be contradictory (witness the para 22 administration saga and the related matters concerned with the potential of Insolvency Rule 7.55 to whitewash procedural irregularities). Uncertainty as to the current law introduces inefficiencies into the insolvency procedure (by requiring applications to court for directions) and causes much concern for practitioners. "Defensive" applications to the court by insolvency practitioners to clarify potential uncertainties are a fact of life and are entirely understandable. More generally the adoption of some form of "prospective overruling" may be a possibility worth evaluating as this would remove some of the concerns of insolvency practitioners that a later court ruling in relation to an insolvency might expose them to historic liability in a case that has already been processed. Unfortunately, the English courts have refused to go down this road in the past, and the policymakers have preferred instead to allay the concerns of practitioners via retrospective legislation (witness the Insolvency Act 1994) or extra statutory concessions in the form of "Crown Statements" (used in the wake of Leyland DAF [2004] UKHL 9 and Nat West Bank v Spectrum Plus Ltd [2005] UKHL 41), but this is a problem that will not go away.

It may well be that a number of these issues are being looked at, and it may well be that any such reviews would favour the status quo. Provided such reflection is happening, we can be reassured. At the last reading there was nothing in the Enterprise and Regulatory Reform Bill 2012 to indicate imminent reform in the aforementioned elements of insolvency practitioner regulation, though there has been pressure from the profession to extend to ambit of section 233 to a wider range of suppliers so as to falcate turnaround opportunities. As commentators on this Bill we must remain alert to new clauses being tabled. 


\section{OVERVIEW}

We have in the UK an effective system for the regulation of insolvency practitioners and in global terms it is highly regarded. It is now heavily regulated and it will be interesting to see if the Cabinet Office's "Red Tape Challenge", which was applied to insolvency practice in September 2012, comes up with any suggestions for deregulation. Unfortunately, our system often means that unsecured creditors gain little when an insolvent company's assets are distributed and insolvency practitioners (who, of course, have to break the bad news to creditors) are invariably held to blame, with the finger being pointed at their apparently high professional costs. This partial perspective (which appeals to politicians of all shades) is unfair if viewed in isolation. Insolvency practitioners are highly professional people who draw upon the services of other highly qualified professionals to facilitate the discharge of their onerous responsibilities. They have a reasonable expectation to be paid at an appropriate rate and to have their expenses met. Equally if they fall short of the required standards of stewardship they should expect sanctions to be visited upon them. If there are problems and consequential costs in the system of clearing up the mess when a limited liability company fails many of them relate to the "front end" of the process in which limited liability is made available to all and sundry with few safeguards being put in place.

There is also the fact that our "love affair" with the institution of security means that notwithstanding the best efforts of insolvency office holders there are few residual assets to distribute to unsecured creditors, even after the reserved fund has been utilised for their benefit. If we wish to improve the operation of the law relating to insolvent companies and to make life more palatable to unsecured creditors it is to these fundamental aspects that serious thought should also be given.

- This is a revised and updated version of a paper delivered by Professor Milman at the Institute of Advanced Legal Studies on November 29, 2012. His forthcoming monograph, The Governance of Distressed Firms, will be published by Edward Elgar later this year.

\section{David Milman}

Professor of Law at Lancaster University; Professorial Associate at Exchange Chambers; Visiting Fellow at the Institute of Advanced Legal Studies (2012).

\title{
Articles for Amicus Curiae
}

Amicus Curiae welcomes contributions, which should be accompanied by the name and contact details of the author. The journal publishes articles on a wide variety of issues, ranging from short pieces of 700-1,200 words and longer articles of 4,000 words of so (the upper limit can be extended where appropriate). Articles should be written in an informal style and without footnotes.

\author{
Anyone interested in submitting a piece should email Julian Harris \\ (julian.harris@sas.ac.uk).
}

